\title{
AGE DISCRIMINATION, JOB SEPARATIONS, AND EMPLOYMENT \\ STATUS OF OLDER WORKERS: EVIDENCE FROM SELF-REPORTS
}

\author{
Richard W. Johnson \\ David Neumark
}

Working Paper 5619

\author{
NATIONAL BUREAU OF ECONOMIC RESEARCH \\ 1050 Massachusetts Avenue \\ Cambridge, MA 02138 \\ June 1996
}

Johnson received support from a National Institute on Aging post-doctoral fellowship (grant 5T32-HD07329-06), and Neumark received financial support from NSF grant SES92-09575 and NIA grant K01-AG00589. We thank Richard Burkhauser and Alan Gustman for helpful comments. This paper is part of NBER's research program in Labor Studies. Any opinions expressed are those of the authors and not those of the National Bureau of Economic Research.

(C) 1996 by Richard W. Johnson and David Neumark. All rights reserved. Short sections of text, not to exceed two paragraphs, may be quoted without explicit permission provided that full credit, including $(\mathcal{C}$ notice, is given to the source. 


\title{
AGE DISCRIMINATION, JOB \\ SEPARATIONS, AND EMPLOYMENT \\ STATUS OF OLDER WORKERS: \\ EVIDENCE FROM SELF-REPORTS
}

\begin{abstract}
This paper explores the prevalence and consequences of age discrimination in the workplace by analyzing self-reports of discrimination by respondents in the National Longitudinal Survey of Older Men. Age discrimination was reported in seven percent of our cases, during the period 1966-1980. Workers with positive reports were much more likely to separate from their employer and less likely to remain employed than workers who report no age discrimination. The estimated effect of reported discrimination remains large and significant even when controlling for the existence of mandatory retirement provisions on the current job. These findings are generally robust to numerous attempts to correct the estimates for the inherent limitations of self-reported data, particularly the potential heterogeneity bias that arises from differences in the propensity to report discrimination, and the possibility that discrimination is reported in response to other negative labor market outcomes.
\end{abstract}

Richard W. Johnson Institute for Health, Health Care

Policy, and Aging Research

Rutgers University

30 College Avenue

New Brunswick, NJ 08903
David Neumark

Department of Economics

Michigan State University

East Lansing, MI 48824

and NBER 


\section{Introduction}

Anecdotal evidence abounds of older workers who have experienced discrimination because of their age. The popular press is replete with stories of individual employees who have been replaced by younger workers, sometimes just before they become eligible for lucrative retirement benefits. Some older workers (in the past) were forced by mandatory retirement provisions to leave their job before they would otherwise have chosen to retire. Others who remain on the job claim that they confront hostile work environments or are demoted to less remunerative positions because of their age. Concern by policy makers over these types of incidents prompted Congress to enact the Age Discrimination in Employment Act (ADEA) in 1968, which outlawed discrimination in the workplace against workers between the ages of 40 and 65 . Later amendments prohibited mandatory retirement before the age of 70 (in 1978) and then outlawed it completely (with a few exceptions) in 1986. During 1990, 10,485 complaints of age discrimination were filed with the Equal Employment Opportunity Commission (Equal Employment Opportunity Commission, 1994). ${ }^{1}$

However, there is little empirical research to document the prevalence or impact of age discrimination in the labor market. In fact, prima facie evidence of discrimination against older workers is less compelling than that for other demographic groups (Friedman, 1984). With respect to labor market indicators frequently studied as evidence of discrimination - income and unemployment (e.g., Lloyd and Niemi, 1979) - older individuals tend if anything to fare better.

Older workers have relatively high labor market earnings, at least into their fifties (Bureau of Labor Statistics, 1989), high non-labor income (Hurd, 1990), and low civilian unemployment rates.

In addition, many economists have questioned the virtue of legislation outlawing mandatory

${ }^{1}$ By comparison, there were 43,532 complaints filed with the EEOC in 1990 under Title VII of the Civil Rights Act of 1964, primarily for alleged discrimination based on sex or race. 
retirement provisions, which are critical components of long-term incentive contracts (Lazear, 1979). In order to elicit effort from workers, employers may initially pay wages below the value of marginal product in exchange for implicit promises of future wages that exceed the value of marginal product for workers who remain with the firm. Mandatory retirement ages then become necessary to induce high-wage workers to leave the firm. Workers find it in their interest to enter into these long-term employment relationships with mandatory retirement, but once they reach the mandatory retirement age they would prefer to continue working at their current wage. By eliminating shirking, however, long-term contracting (with mandatory retirement) in the Lazear model is efficient, leading Lazear to argue that legislation to ban mandatory retirement contracts enables current older workers to "enjoy a small once-and-for-all gain at the expense of a much larger and continuing efficiency loss that affects all workers and firms adversely" (Lazear, 1979, pp. 1283-84). Nonetheless, the ADEA may have a sound rationale if employers engage in discriminatory practices against older workers. Thus, the ADEA cannot be fairly evaluated before first assessing the prevalence and impact of age discrimination in the labor market, ideally relying on data prior to the proliferation of age discrimination lawsuits.

The inherent difficulty in measuring age discrimination probably accounts for the lack of attention devoted to it by economists. Many analyses of sex and race discrimination in the labor market proceed from the assumption that women and members of racial minorities are as productive as men and white workers, after controlling for other observable factors that are likely to affect productivity. Differences in earnings that persist after controlling for human capital and other variables are then attributed to labor market discrimination. However, this approach is clearly not appropriate for the analysis of age discrimination, since the very process of aging is likely to affect worker productivity. On one hand, older workers have more experience, which generally 
increases productivity; on the other hand, skills may deteriorate with age after a certain point, reducing productivity. ${ }^{2}$ Regardless of which effect dominates, the assumption that older workers are equally productive as younger workers - controlling for variables such as education, experience, and tenure - is not compelling.

In this paper, we take a different approach to the analysis of age discrimination by investigating self-reports of age discrimination. We assess the effects of age discrimination by comparing labor market outcomes for older workers who claim that they have experienced discrimination on the job with outcomes for workers who do not report discrimination. Although the use of self-reports can be problematic - primarily because individuals may differ systematically in their propensity to report discrimination, and because such reports may reflect negative outcomes that are, in fact, unrelated to discrimination - in the absence of actual measures of productivity, self-reports may offer the best available indicators of age discrimination. ${ }^{3}$ We are also able to mitigate many of the problems associated with self-reports by comparing an individual's responses at different points in time and by utilizing some of the rich information available in the data to control for potentially confounding factors.

In contrast to investigating earnings, which is generally the outcome of interest in studies of sex and race discrimination, this paper focuses on the effects of age discrimination on job separations and spells of non-employment, both of which may be precursors to full or partial

${ }^{2}$ For evidence of such productivity declines see Hellerstein, et al. (1996).

${ }^{3}$ Audit studies (see, e.g., Fix and Struyk, 1992) provide another tool for studying discrimination. However, we are unaware of any academic audit studies assessing the role of age discrimination in hiring, nor are they likely to prove very helpful in this particular context. One problem is that such methods are useful primarily for studying entry-level jobs, which may not be the jobs in which age discrimination is likely to occur. A second problem is that such studies attempt to make workers identical (at least on average) on paper, except for the demographic characteristic being studied. But it is not possible to make older and younger individuals identical on paper without giving the older individual extremely low job experience, causing this individual to appear anomalous (Bloch, 1994). 
retirement (Ruhm, 1990). Of course, separations and changes in employment status are often undoubtedly voluntary, and do not reflect discriminatory behavior against older workers. However, they may sometimes stem from discrimination, as suggested by the greater prevalence of discouraged workers among the old (Rhine, 1978), by evidence of managerial preferences for younger workers (Rosen and Jerdee, 1977), and by research indicating that older workers experience discrimination with respect to mobility and layoffs (Parnes and King, 1977; Hutchens, 1988).

Our findings suggest that age discrimination may be an important factor in determining job separations and employment status of older workers. Approximately seven percent of our sample of older workers report having experienced age discrimination in the workforce, and these workers are much more likely to separate from their employer and to experience spells of non-employment than workers who do not report age discrimination. The estimated effect of reported discrimination remains large and significant even when controlling for the existence of mandatory retirement provisions on the current job, implying that self-reported age discrimination is not just reflecting ex post dissatisfaction with these provisions (Lazear, 1979). These findings are generally robust to our attempts to correct our estimates for inherent limitations of self-reported data.

\section{Data}

To assess the impact of age discrimination on job separations and employment status, we analyze data from the National Longitudinal Survey of Older Men (NLSOM). The NLSOM collected information in 1966 on a national probability sample of 5,020 men between the ages of 45 and 59. They were surveyed periodically until 1983, at which time they ranged in age from 62 to $76{ }^{4}$ At each interview, respondents were questioned about their labor force participation. For

${ }^{4}$ Respondents were interviewed in 1966, 1967, 1968, 1969, 1971, 1973, 1975, 1976, 1978, 1980, 1981, and 1983. A final follow-up was conducted in 1990, but given the time lag between this final 
those at work, detailed information was collected on job characteristics, including years of job tenure, occupation, industry, sector, mandatory retirement provisions, hourly wages (for some years), and employment status, plus information about whether workers changed employers since the previous interview. Pension coverage on the current job is available only in 1966 (as well as selected years late in the panel). The survey also solicited information periodically about men's attitudes toward their current job, asking them if they liked their job very much or fairly well, or if they somewhat or very much disliked it. ${ }^{5}$

Of particular interest for this study, and one of the unusual aspects of the survey, is the information it includes about age discrimination. In 1971, 1976, and 1980, men were asked the following question:

During the past five years, do you feel so far as work is concerned, you were discriminated against because of your age?

Those who reported discrimination were then asked about the basis for their claims, and could cite any of the following reasons: they were not hired or interviewed because of their age; they were not promoted or assigned to a certain job because of their age; they were demoted or laid off because of their age; they just feel the company discriminates; they feel there is general discrimination throughout society; or some other unspecified reason.

\section{Empirical Approach}

The basic empirical strategy of this paper is to track the employment behavior of older workers following a self-report of discrimination, to determine whether or not those who report discrimination are subsequently more likely either to leave their current employer or to experience

interview and the previous interview and the age of the respondents (who range in age from 69 to 83 in 1990), we chose not to analyze these data here.

${ }^{5}$ Information on union membership is available for only selected years of the panel, and thus is not incorporated into our analysis. 
spells of non-employment than otherwise similar workers. Even if such an empirical relationship is found, however, there are reasons to be cautious in concluding that a causal relationship exists among older workers between age discrimination in the labor market and job separations and changes in employment status. Consequently, this paper takes a number of different approaches to assessing alternative explanations of such a finding.

To assess the impact of age discrimination, we estimate discrete-time hazard models of job separations and employment status. This approach has been taken by a number of studies of unemployment and retirement, including Ham and Rea (1987) and Blau (1994). For each respondent in the sample, we create a separate record for each year he works for pay. Men who stop working at some point but subsequently return to work re-enter the sample once they resume working. Each time the respondent is observed at work, we observe two dichotomous outcomes he either remains at the current job into the next period or he leaves; and he is either employed in the next period or not. These outcomes are assumed to depend upon a set of predictors, many of which vary over time.

We assume that each worker has an underlying propensity to leave their current employer, which we model as a function of self-reported discrimination and other controls, ${ }^{6}$

$$
L^{*}{ }_{i t}=\alpha+X_{i t} \beta+D_{i t} \gamma+\epsilon_{i t}
$$

$\mathrm{L}^{*}$ it is the propensity of individual $\mathrm{i}$ to leave the employer at time $t, \mathrm{X}_{\mathrm{it}}$ is a vector of control variables, $\mathrm{D}_{\mathrm{it}}$ is a dummy variable equal to one if the individual reports age discrimination during some period before time $t$, and zero otherwise, and $\epsilon_{\mathrm{it}}$ is a random disturbance term. $\mathrm{L}^{*}{ }_{\text {it }}$ is not observed; instead we observe a dummy variable $\mathrm{L}_{\mathrm{it}}$ which equals one if $\mathrm{L}^{*}$ it exceeds some threshold (normalized to zero), and zero otherwise. Thus, the probability that we observe a job separation is study.

${ }^{6} \mathrm{We}$ could equivalently frame the discussion in terms of employment status, the other outcome we 
equal to $1-F\left(-\alpha-X_{i t} \beta-D_{i t} \gamma\right)$, where $F$ is the cumulative distribution function for $\epsilon$. If we assume that $\epsilon$ follows a logistic distribution, we can estimate the parameters of (1) as a logit model. In this equation, a positive estimate of $\gamma$ would indicate that individuals who report discrimination are more likely to subsequently separate from their employer.

There are, however, a number of problems with inferring a causal impact of age discrimination on job separations from the estimate of $\gamma$ in equation (1). First, there is evidence from existing work with self-reported discrimination data (on sex discrimination) that there may be an important heterogeneity problem with respect to which individuals report discrimination (Kuhn, 1987). In the present context, our estimates of $\gamma$ would be biased if an individual's propensity to report age discrimination were correlated with certain labor force activities. For example, individuals who are highly committed to working at relatively old ages may be less likely to report age discrimination, regardless of the actual level of discrimination experienced. In this case, there would be a bias towards finding that discrimination leads to changes in employment, when in fact the association would not represent a causal relationship stemming from discrimination.

One solution to this problem is to exploit the fact that most respondents provide more than one self-report of age discrimination over the course of the panel. Workers who change their reports (in either direction) provide valuable information on discrimination that may be independent of individual-specific propensities to report discrimination. Thus, by identifying the "effect" of discrimination from the labor market behavior of those who switch to reporting discrimination, we may be better able to estimate the causal effect of discrimination on the employment decisions of older workers (see Neumark and McLennan, 1995). Focusing on multiple responses from a given individual will not necessarily eliminate heterogeneity bias, however, because there may be variation in the propensity to switch to reporting discrimination. 
Nonetheless, the use of multiple responses should go a long way in reducing heterogeneity bias.

Multiple discrimination reports can be incorporated into the hazard model in two ways.

First, we can replace $D_{i t}$ in equation (1) with three dummy variables to identify whether and in which direction reports of discrimination change. The equation defining our latent variable on which we base our logit estimates becomes

$$
\mathrm{L}^{*}{ }_{\mathrm{it}}=\alpha+\mathrm{X}_{\mathrm{it}} \beta+\mathrm{ND}_{\mathrm{it}} \delta+\mathrm{DD}_{\mathrm{it}} \phi+\mathrm{DN}_{\mathrm{it}} \lambda+\epsilon_{\mathrm{it}},
$$

where $\mathrm{ND}_{\mathrm{it}}$ is a dummy variable set equal to one if a worker at time $t$ who had previously reported no discrimination then reports discrimination, $\mathrm{DD}_{\mathrm{it}}$ is a dummy variable which equals one if the worker reports discrimination continuously through time $\mathrm{t}$, and $\mathrm{DN}_{\mathrm{it}}$ is a dummy variable which equals one if a worker who once reported discrimination subsequently reports no discrimination at time $t^{7}$ The reference group is workers who never report discrimination through time $t$. If the fixed propensity to report discrimination (independent of its actual existence) were positively correlated with job separations, then the magnitude of $\phi$ would be large relative to $\delta$ and $-\lambda .^{8}$ We would claim stronger evidence of age discrimination having a causal effect on separations if we were to find that $\delta$ in equation (2) were significantly greater than zero, and that $\lambda$ were significantly less than zero, although we regard the latter implication as less compelling since worker attachment may be affected by past discrimination.

A second approach to using multiple reports to reduce the heterogeneity problem is simply to restrict the analysis to the subset of individuals who do not report discrimination (and are employed) the first time they are asked. Then, equation (1) can be estimated where $D_{i t}$ is the of time $t$.

${ }^{7}$ In all cases, the second report used in defining these dummy variables is the most recent report as

${ }^{8}$ The parameter would also be large if the impact of discrimination experiences were cumulative, so that workers are more likely to leave a job the more often they experience discrimination. 
response to the discrimination question the second or third time it is asked. By estimating the equation for this subset of individuals, the heterogeneity problem should be eliminated or at least reduced because $\gamma$ is estimated conditioning out differences in initial responses to the discrimination question.

A second problem is that individuals may incorrectly attribute to age discrimination negative outcomes that are in fact unrelated to such discrimination, perhaps to rationalize these negative outcomes. Because they may respond to these negative outcomes by leaving their employer or the labor force, we could then obtain spurious evidence of an effect of age discrimination. We explore this potential problem by comparing the impact of discrimination reports based on age with reports based on other factors, such as race. Some critics of age discrimination legislation argue that these laws merely provide middle-aged white men the opportunity to sue employers for negative job outcomes, as blacks, Hispanics, and women have been able to do since the passage of the Civil Rights Act of 1964 (see Friedman, 1984, for examples). If this view is accurate, then non-whites should be less likely to report age discrimination, and instead report race discrimination as the "cause" of an adverse labor market outcome, particularly if race discrimination reports are seen as more credible than reports of age discrimination. More importantly, the effect of age discrimination reports on job separations and employment status should be considerably smaller for non-whites than for whites, while race discrimination should be strongly associated with job separations and non-employment for nonwhites. Since the NLSOM includes questions about discrimination based on race, religion, and nationality, in addition to age, we can test this idea by separately analyzing reports of age discrimination among non-whites, comparing the effects of reported age discrimination and race discrimination (and the incidence of the former). 
A third problem with the interpretation of estimates of equation (1) is that workers facing the prospect of mandatory retirement as part of long-term incentive contracts might nonetheless report age discrimination prior to retirement, because mandatory retirement is involuntary ex post on the part of the worker. In this case, evidence of a link between reported age discrimination and subsequent job separations or changes in employment status would not provide evidence in favor of age discrimination or against long-term contracts. Rather, the self-reports would simply reflect workers' ex post dissatisfaction with the prospect of mandatory retirement. A solution to this problem is to exploit the information in the NLSOM about the existence of mandatory retirement provisions on the current job. We therefore add a dummy variable $\mathrm{MR}_{\mathrm{it}}$ to equation (1), to indicate whether a worker faced mandatory retirement during the period covered by the discrimination selfreport, as in

$$
\mathrm{L}^{*}{ }_{\mathrm{it}}=\alpha+\mathrm{X}_{\mathrm{it}} \beta+\mathrm{D}_{\mathrm{it}} \gamma+\mathrm{MR}_{\mathrm{it}} \theta+\epsilon_{\mathrm{it}}
$$

and test whether $\gamma$ is greater than zero (or the corresponding test for equation (2)).

We also introduce additional explanatory variables into the estimating equations. For example, we control for workers' attitudes toward their current job. Disentangling the effects of general dissatisfaction with one's job from the effects of reported age discrimination reduces the likelihood that our estimates of the effects of discrimination merely reflect negative job characteristics or outcomes, which should be captured by the attitudinal measure. In some of our regressions, we also interact the age discrimination indicator with the worker's age and control for the reasons cited by respondents for their age discrimination reports, since workers who claim discrimination because of treatment received on the current job may be more likely to leave that job than workers who report discrimination because they were not hired or interviewed for another job. A final problem we confront arises from limitations of the structure of the data. Workers 
are asked whether they have experienced age discrimination at any time over the past five years. Thus, we can link discrimination to a particular job only for those workers who work at only one job during the entire five-year period. Although we conduct some of our analyses on samples restricted to workers with only one employer in any five-year period, the selectivity of this sample makes these results somewhat suspect, since workers who remain with an employer perceived to engage in discriminatory practices may not be typical of most workers. Most of our analysis is instead based on the entire sample of workers, and we are in effect assuming that workers who experience any discrimination in the past five years experience discrimination in all jobs over that period. For example, a worker who reports age discrimination over the last five years in 1971 is treated as if he reports discrimination continuously from 1966 to 1971, and we study the relationship between discrimination reported in 1971 and subsequent behavior. By sometimes incorrectly assigning reported discrimination to jobs where none is perceived, this approach will generate downward-biased estimates of the effect of age discrimination on employment. Given that we find evidence of effects of age discrimination, this source of bias only strengthens our conclusions.

\section{Description of Sample}

The NLSOM data that we analyze cover the period 1966 to 1980 . While these data are not very recent, we think it is instructive to study the effects of age discrimination in the period prior to passage or rigorous enforcement of the ADEA, in order to assess whether the ADEA was responding to legitimate concerns regarding age discrimination. Although the ADEA was passed in 1968, responsibility for its enforcement rested with the Department of Labor until 1978, and few resources were devoted toward this goal. In 1978 enforcement shifted to the EEOC, and the director of that agency sought to give age discrimination the same emphasis as race and sex 
discrimination. This seemed to occur. The Department of Labor received about 1,000 complaints of age discrimination in 1969 , which climbed to 5,000 in 1976 . By 1982, after enforcement had switched to the EEOC, the number of complaints climbed to 11,000. (Friedman (1984) provides a historical overview of the ADEA.) The ADEA also had more significant effects beginning in 1978 because amendments to the Act increased the mandatory retirement age from 65 to 70 in that year, bringing many additional workers under its protection.

Our extract includes observations on all survey years in which a respondent was working at a job, from 1966 to 1980 , for a total of 19,270 observations on 3,001 respondents. ${ }^{9}$ (Since information on discrimination is not available in 1981 and 1983, observations for these years are not included in the sample. However, employment information in 1981 is used to identify workers who leave employers or become non-employed between 1980 and 1981.) Sample means, for the person-year observations, are reported in columns 1-3 of Table 1, first for all workers and then separately for those who do and do not report age discrimination.

Overall, 22 percent of workers leave their job each year, and about one-half of these separations lead to a spell of non-employment. The incidence of spells of non-employment increases sharply with age. Almost one-fifth of workers over the age of 55 are not employed at the following interview, compared to only four percent of workers age 55 and younger. For 47 percent of all observations, workers are subject to mandatory retirement, and for 65 percent of the observations workers received pension coverage on the job they held in 1966. Health limitations, defined each year as health problems which the respondent claims limit the amount or type of work

${ }^{9}$ All observations for men who were not working in 1966, or were self-employed in 1966, were first eliminated from the sample. In addition, all observations with missing discrimination reports in any year were excluded from the analysis. When other variables used in the analysis are missing in a particular year, the value of the variable is set equal to zero and the corresponding missing variable dummy is set equal to one. 
he is able to perform, affect 23 percent of the sample. Only six percent of the sample dislike (either somewhat or very much) their current job. The mean level of tenure on the current job is 14.6 years. Twenty percent of the sample is employed in the public sector.

Approximately seven percent of the observations include positive reports of age discrimination that occurred over the past five years. The incidence of discrimination reports is somewhat higher among workers over age $55(8 \%)$ than among workers age 55 and younger (6\%). Workers who report discrimination are much more likely to separate from their jobs during the next period ( $37 \%$ vs. $21 \%)$ and to experience a spell of non-employment (18\% vs. $11 \%)$. These differences hold both for workers age 55 and younger and for those over 55 , although the differences are larger in relative terms for the younger group. As a result of their higher separation propensities, workers reporting discrimination have 2.5 fewer years of job tenure, on average, than workers who report no discrimination. Reporters and non-reporters appear to differ systematically in other ways, as well. For example, those who report age discrimination have significantly more schooling and more health problems and are significantly less likely to have had pension coverage in 1966 or to be employed in the public sector. Non-reporters in the sample have higher hourly earnings and are much less likely to dislike their job.

As a purely descriptive exercise to reveal the partial associations between reported age discrimination and the other explanatory variables in our model, we estimate a logit equation for reporting discrimination. Results are presented in column 4 of Table 1, with standard errors reported in parentheses and odds ratios in square brackets. As we expected, dissatisfaction with the current job is strongly positively correlated with discrimination reports; the likelihood of reporting discrimination is more than twice as high among disgruntled workers than among workers who are at least somewhat content with their job, holding other factors constant. Workers with health 
problems, divorced workers, and workers subject to mandatory retirement ages on the job are also much more likely to report discrimination. Age and schooling also have significant positive associations. Workers with higher wages and more years of experience with the employer, however, are significantly less likely to claim discrimination, as are those in the public sector and those who were covered by pension benefits on the job held in 1966 . Race does not appear to have a significant effect on the likelihood of reporting age discrimination. The significant associations of reported age discrimination with observable characteristics of workers highlights the importance of attempting to eliminate bias from heterogeneity in the propensity to report discrimination.

\section{Results}

\section{Job Separations}

Estimates from our basic hazard model of job separations are reported in Table 2. The dependent variable is equal to one if the worker leaves his current employer before the next interview (in either one or two years, depending on the interview year), and zero otherwise. In column 1, the explanatory variables include the self report of age discrimination, year dummies to capture macroeconomic influences on individual labor market decisions and differences in the number of years until the next interview date (and thus differences in the length of exposure to the risk of job separation), and personal characteristics of the worker (the presence of any health limitations, years of completed schooling, race, marital status, SMSA residence, and age entered up to a quartic). ${ }^{10}$ Column 2 adds mandatory retirement provisions to the specification. A dummy variable indicating the existence of a mandatory retirement age on the current job is interacted with three age dummies, to enable the effects of mandatory retirement to differ for workers age 55 and

\footnotetext{
${ }^{10}$ In specifications not reported here, the year dummies were replaced by a dummy variable identifying two-year survey intervals. As expected, the likelihood of separating from the current employer is greater during these longer intervals than during the one-year intervals.
} 
younger, older than 55 but younger than 65 , and older than 65 . Other job characteristics are added in column 3, including an indicator for pension coverage on the job held in 1966, years of experience on the current job (up to a quartic), a dummy variable identifying jobs held in the public sector, and one-digit industry and occupational controls. This specification is repeated in column 4, after dropping the industry and occupational controls and including among the covariates the predicted value of the real log wage (to avoid bias from influences of anticipated future behavior on wages); the real wage is predicted by ordinary least squares, utilizing all the covariates included in column 3. Column 5 adds a dummy variable to identify workers who report that they somewhat dislike or very much dislike their current job. Column 6 repeats this specification, but excludes the predicted wage and includes the occupational and industry controls in the estimating equation. Finally, column 7 repeats column 6 after introducing interaction terms to permit the effect of reported age discrimination to differ between workers age 55 and younger and those older than age 55.

The estimated coefficients on self-reported age discrimination presented in Table 2 are positive, large, and statistically significant. In column 1, with the fewest controls, workers reporting age discrimination are more than twice as likely to separate from their employer than are workers who report no age discrimination. The estimated coefficient is quite robust to changes in the way the estimating equation is specified. For example, although the inclusion of the full set of controls in columns 5 and 6 reduces the size of the estimated coefficient by about 20 percent, relative to column 1 , the reported odds ratios indicate that workers with positive reports are still 1.9 times as likely to separate as workers who do not report discrimination. The logit model estimated in column 5 indicates that workers who report no age discrimination in 1966 will remain with their 
current employer for 1.2 years longer than workers who report discrimination. ${ }^{11}$ Although discrimination reports are somewhat more prevalent among workers over the age of 55 , the estimated effect of reporting discrimination is substantially larger for workers age 55 and younger, who may have more alternative employment options than older workers.

Mandatory retirement provisions appear to affect job separation rates. However, the inclusion of mandatory retirement in the estimating equation does not reduce the magnitude or significance of the age discrimination coefficient, as can be seen from comparing columns 1 and 2 , suggesting that workers are referring to employment practices that extend beyond the imposition of mandatory retirement ages when they report age discrimination. Workers between the ages of 56 and 65 on jobs which impose mandatory retirement ages are significantly more likely to separate from their employers than workers on jobs with no mandatory retirement provisions, presumably because these workers have reached the mandatory retirement age and are required to leave. The estimated incremental effect ranges from 17 to 32 percent, depending upon the specification. ${ }^{12}$ For workers under 55 , mandatory retirement provisions sharply decrease separation rates. This effect is consistent with Lazear's long-term incentive contracts. According to Lazear's model, senior workers in firms with mandatory retirement provisions earn wages above the value of their marginal product, or expect to earn high wages in the near future, which discourages them from leaving the firm. Mandatory retirement has no significant effect on workers after age 65 , an age at

"Based on the model estimates, the expected number of additional years on the current job for workers in 1966 who never report age discrimination is 7.9 years, whereas for workers who always report age discrimination expected additional years on the job is 6.7 years. For this calculation, other variables in the model were set at their sample means, with tenure and age increasing each year after 1966.

${ }^{12}$ The coefficient on the mandatory retirement dummy for workers ages 56 to 65 is negative in column 2, however, when industry and occupation controls (and all other job characteristics) are excluded from the specification, suggesting that the imposition of mandatory retirement provisions varies by industry and occupation. 
which very few workers are still subject to mandatory retirement provisions.

Another possible explanation for the strong observed effect of age discrimination on job separations is that workers who are simply unhappy with their job - perhaps because of some negative job characteristic or outcome unrelated to discrimination - separate and nonetheless claim discrimination. Including an indicator of job dissatisfaction helps to solve this problem, as long as any such negative characteristics or outcomes are reflected in reported dissatisfaction. Indeed, we find that dissatisfied workers, who report that they somewhat dislike their current job or dislike it very much, have much higher separation rates than men who are more content with their job. The probability of a job separation is 74 percent higher among workers reporting job dissatisfaction. However, the size of the discrimination effect falls only slightly, by less than ten percent, when job dissatisfaction is added to the estimating equation. Thus, the basis for claiming age discrimination appears to go beyond general dissatisfaction with one's employer.

Many of the other explanatory variables in the model have significant effects on job separations. Separation rates are higher among workers who are relatively old, experience health problems that limit their ability to work, and earn high wages. These characteristics have also been shown to increase retirement probabilities (e.g., Quinn, et al., 1990). Separation rates are lower among workers who are married, well-educated, and employed in the public sector, and who have many years of experience with the current employer and received pension coverage on the job held in 1966 . Separation rates do not vary significantly by race, controlling for the real wage. ${ }^{13}$

\footnotetext{
${ }^{13}$ The standard errors reported in Table 2 may be understated, due to the dependence among repeated observations on individuals. To assess the influence on our conclusions of downward bias in our standard errors, we re-estimated the model on a sample restricted to one randomly-selected observation per respondent. The estimated effects of reported age discrimination remain large and highly significant. For example, the coefficient on reported age discrimination is 0.83 , with a standard error of 0.16 , for the model in column 5 , and 0.82 , with a standard error of 0.16 , for the model in column 6 .
} 


\section{Changes in Employment Status}

To this point, our analysis of job separations has ignored the employment status of separated workers. However, workers who leave their current job have several options: they can move to another job, become self-employed, or stop working altogether. We turn now to the question of whether perceived age discrimination increases the likelihood that workers will separate from their employer and not find employment elsewhere.

The hazard models are re-estimated using the same specifications as in Table 2, except that now the dichotomous dependent variable each year is equal to one only if the worker does not report any work at the subsequent interview. We do not separately identify individuals who are actively seeking work but remain unemployed, since the distinction between these workers and discouraged workers is often arbitrary (Clark and Summers, 1979) ${ }^{14}$ The results, which are reported in Table 3, tell the same basic story as the findings for job separations. As before, the estimated coefficients on reported age discrimination are positive, large, and statistically significant, and robust to the inclusion of additional controls in the estimating equation. Workers who report discrimination are between 72 percent and 83 percent more likely to experience a spell of non-employment than workers who report no discrimination, depending upon the exact specification. Workers between the ages of 56 and 65 subject to mandatory retirement provisions and workers who report job dissatisfaction are much more likely to experience a spell of nonemployment than are workers not subject to mandatory retirement and workers content with their jobs. ${ }^{15}$ However, controlling for these factors has little effect on the size or significance of the

\footnotetext{
${ }^{14}$ This may be particularly true for old workers for whom discouragement is more prevalent (Rhine, 1978).

${ }^{15}$ Mandatory retirement provisions do not affect employment rates for workers younger than 56 or older than 65 .
} 
discrimination coefficient, suggesting once again that age discrimination reports do not simply reflect dismay over mandatory retirement or general job dissatisfaction. The estimates reported in column 5 imply that workers who report no discrimination remain employed for 0.6 years longer than workers who report age discrimination. ${ }^{16}$ Relatively young workers (age 55 and under) with positive reports are less likely to be employed than older workers who report discrimination.

The effects of other variables in the model are generally consistent with the retirement literature. Rates of employment are lower among workers who are relatively old, experience health problems, and earn high wages. ${ }^{17}$

\section{Correcting For Potential Heterogeneity Bias}

The estimated impact of age discrimination on job separations and employment status reported in Tables 2 and 3 may be biased upward if heterogeneity in the propensity to report discrimination results in those workers who report discrimination being more likely to leave their jobs, independent of any causal effect of discrimination, as noted in Section III above. Some indication of the extent to which individual-level heterogeneity affects the propensity to report discrimination may be provided by exploring the persistence of age discrimination reports over time. If positive discrimination reports arise largely from the propensity of individuals to claim discrimination, regardless of the actual behavior of employers, then discrimination reports by a given individual are likely to be relatively consistent over time. In particular, an individual who

\footnotetext{
${ }^{16}$ The model predicts that in 1966, for a worker with mean characteristics who never reports discrimination, expected additional continuous years of employment is 8.8 years, compared with 8.2 years for the mean worker who reports discrimination.

${ }^{17}$ To assess the influence of downward bias in our reported standard errors, we again re-estimate the models on a sample restricted to one random observation per respondent. The discrimination coefficients corresponding to columns 5 and 6, respectively, are 0.41 with a standard error of 0.20 and 0.37 with a standard error of 0.21 . Thus, the evidence is a bit weaker for changes in employment status than for separations overall.
} 
reported discrimination in the past would be likely to report discrimination in the future, even after moving to a different employer. If, however, discrimination reports were based solely on employer practices, then individuals with positive reports in the past would be no more likely to report discrimination after changing employers than workers who never reported discrimination.

We investigate persistence in discrimination reports by relating the likelihood of reporting discrimination in the years 1973-1976 and 1978-80 to earlier discrimination reports, permitting the relationship to differ between workers who reported past discrimination by former employers and workers who reported past discrimination by current employers. Logit estimates are reported in columns 1 and 2 of Table 4, for specifications which include the full set of controls as in columns 5 and 6 , respectively, of Table 2 . Workers with positive past reports are significantly more likely to report discrimination in the current period. The coefficient on past discrimination is much larger for individuals who continue to work for the same discriminating employer than for workers who have moved to new employers, suggesting that many of these reports reflect employer-specific behavior. However, the large and positive effect on current discrimination of past discrimination reports that relate to former employers suggests that certain workers - even after they change employers - may be more likely to report discrimination than others, regardless of employer behavior. Thus, if those workers who are more prone to report discrimination are also more likely to leave their current job, the estimates reported in Tables 2 and 3 may be partly driven by heterogeneity, not the causal effect of age discrimination on job separations and employment status.

We confront the heterogeneity problem by focusing on workers whose discrimination reports change over the course of the panel, in effect conditioning out individual differences in reporting behavior. Panel A of Table 5 presents estimates based on the same specifications described in columns 5 and 6 of Tables 2 and 3 (which utilize the full set of control variables), but 
replacing the single dummy for reported age discrimination with three dummy variables which serve to separately identify workers who switch discrimination reports, workers who always report discrimination, and workers who never report discrimination. The construction of these variables is described below.

Each of the three dummies is defined as of the year of the observation. Between 1966 and 1971, workers are coded as "reports age discrimination continuously" if they report discrimination in 1971 . They are coded similarly from 1972 to 1976 if they report discrimination in 1971 and 1976, and likewise for 1977-80 if they report discrimination all three times (in 1971, 1976 and 1980). About five percent of the sample reports age discrimination continuously. The second dummy defines workers who switch to reporting discrimination. By definition, this variable equals zero for all workers during years 1966-71. From 1972-76, it is set equal to one for workers who did not report discrimination in 1971 but subsequently report discrimination in 1976 . The "switching to reporting discrimination" dummy equals one from 1977-80 for workers who report discrimination in 1980 but did not report any in 1971, 1976, or either year. About two percent of the sample observations are included in this category. The final dummy defines workers in years they switch from reporting discrimination to reporting no discrimination, and is defined in the same manner as the "switching to" variable. This variable is equal to one for 1.6 percent of the observations.

Turning to Panel A of Table 5, we see that workers who report discrimination continuously are much more likely to leave the current employer than workers who never report discrimination or who report discrimination in some but not all years. Controlling for the full set of personal and job characteristics, the predicted real wage, and attitudes toward the job, workers with continuous discrimination reports are more than twice as likely as non-reporters to separate from their jobs. 
Workers who report discrimination after having reported no discrimination in a previous period are about one-half as likely to leave the current employer as workers who report continuously. Although this result might reflect the more persistent discrimination experienced by the latter group of workers, it also may identify intrinsic differences in job separation behavior between those who do and do not report discrimination continuously (i.e., heterogeneity bias). Nonetheless, we continue to find strong evidence for a causal effect of reported job discrimination on job separations; hazard rates are almost 50 percent higher among workers who switch to reporting discrimination than among workers who never report discrimination. ${ }^{18}$

Turning to employment status, the impact of continuously reporting age discrimination is quite similar in magnitude to the effect we estimate for job separation rates. Workers who continuously report discrimination are more than twice as likely to experience a spell of nonemployment as workers who never report discrimination. However, switching to reporting age discrimination has a much smaller positive effect on the employment hazard, suggesting that much of the effect of discrimination reports on employment status estimated in Table 3 may simply reflect heterogeneity bias. The estimated effect is insignificant in column 3 , and is marginally significant $(\mathrm{p}<.12)$ in column 4 . Switching from reporting discrimination has an insignificant negative effect on the employment hazard, which is the anticipated sign if discrimination discourages employment.

An alternative way to implement this approach to the heterogeneity problem is to analyze the impact of perceived age discrimination among workers who initially report no discrimination (in 1971). The specifications from columns 5 and 6 of Tables 2 and 3 are repeated for the years

\footnotetext{
${ }^{18}$ No significant effect on job separations was found for reporting no discrimination after having made a positive report in a previous period. As mentioned earlier, we do not interpret this last result as strong evidence against an effect of age discrimination on separations, since the impact of past discrimination may persist into subsequent periods.
} 
1973-80 for the sample of initial non-reporters. More than six percent of the observations in this sample include positive discrimination reports. Estimated effects of reported age discrimination for this sample, reported in Panel B of Table 5, are substantially smaller than the corresponding estimates in Tables 2 and 3, but they are nonetheless large and statistically significant. Among workers who initially report no discrimination, workers who later provide positive reports are about 60 percent more likely to separate from their employer and up to 39 percent more likely to experience a spell of non-employment than workers who never report age discrimination. Although these results confirm our suspicion that part of the observed effect of discrimination reports reflects heterogeneity in the propensity to report discrimination, they also provide evidence that age discrimination has real effects on job separations and employment status, with the evidence particularly strong for separations. ${ }^{19}$

The other main problem with interpreting the evidence as identifying causal effects of discrimination is that workers may incorrectly attribute to discrimination other adverse labor market outcomes, to which they respond by leaving their job. We address this issue by focusing on the reports of non-white workers. Non-whites may be less likely than whites to attribute problems in the workplace to age discrimination, because they can "attribute" their problems to race discrimination, which may be more credible. Table 6 reports the results of re-estimating the logit equations of columns 5 and 6 of Tables 2 and 3 and columns $1-4$ of the lower panel of Table 5 on a sample of non-white workers. In addition to the covariates in the earlier estimations, the equations now include an indicator for reporting discrimination based on race, religion, or

${ }^{19}$ When the sample is further restricted to one random observation per respondent to correct for the potential underreporting of standard errors, the estimated effects of age discrimination on job separations becomes marginally significant $(p<.09)$ in column 1 of Panel $B$, but remains significant $(p<.05)$ in column 2 . The estimated effect on employment status become insignificant, as the standard errors in columns 3 and 4 increase to 0.20 and 0.18 , respectively. 
nationality. Among all observations on non-white workers in our sample, 6.8 percent report age discrimination and 6.5 percent report other types of discrimination (most of which are based on race).

The percentage reporting age discrimination is essentially the same as for the full sample, indicating that white males are hardly more likely to report age discrimination; in and of itself, this casts doubt on the interpretation of reported age discrimination as reflecting primarily other adverse labor market outcomes. More importantly, the estimated effects of age discrimination on job separations and employment status among non-whites are quite similar to the observed effects among all workers. Non-white workers who report age discrimination are about twice as likely both to separate from their employer and to experience a spell of non-employment as non-whites who report no age discrimination. This effect is much larger than the effect of race and other types of reported discrimination. Non-white workers who report other types of discrimination are only 39 percent to 45 percent more likely to separate from their job than workers who do not report other types of discrimination. The effect of other types of discrimination on employment status is small and insignificant. When the sample is restricted to non-white workers who initially report no discrimination, in order to reduce potential heterogeneity bias, the results, as reported in Panel B of Table 6, are again quite similar to the results for workers of all races. Non-white workers who report age discrimination in the later years of the panel are between 60 percent and 75 percent more likely to separate from their job and about 30 percent more likely to experience non-employment, than are non-white workers who never report age discrimination. However, the estimated effects on employment status are statistically insignificant. The observed effect of other types of reported discrimination disappear when the sample is restricted to non-white workers who initially report no age discrimination. The results in Table 6 bolster the validity of the age discrimination self reports. 


\section{Additional Tests of Robustness}

Tables 7 and 8 report on additional analyses designed to further test the robustness of our estimates of the effects of age discrimination on job separations and employment status. We investigate the impact of restricting the sample to workers with only one employer over the period during which they report discrimination, and of allowing the effects of discrimination to vary by the reason respondents give for their discrimination reports, for a sample restricted to workers who initially report no discrimination.

Workers claim age discrimination of different types, and our interpretation of the effect of discrimination on job and labor force attachment can depend upon the type of discrimination cited by workers in their self-reports. In particular, workers who report discrimination because they were not hired or interviewed because of their age may react differently than workers who base their age discrimination claims on other factors. On one hand, discrimination based on witheld job offers or interviews is unlikely to lead workers to leave their current job, since the discriminatory behavior would not generally have been committed by the current employer. Hence, the inclusion of discrimination of this type with other types of discrimination may bias downward the overall estimated effect of age discrimination on job separations. On the other hand, workers who report discrimination because they were unable to secure certain jobs or interviews were presumably seeking new employment in the recent past and may be more likely to leave future jobs or to withdraw from the labor force than other workers, leading to upward biased estimates of the effect of overall age discrimination on job separations and employment status.

To account for these possibilities we distinguish reports of age discrimination based on lost job offers and interviews from other types of age discrimination that more plausibly reflect treatment received on the current job. Among workers who initially report no discrimination, 
approximately ten percent of workers who subsequently report discrimination claim that the discrimination occurred because they were not hired or interviewed ${ }^{20}$ Logit equations for both job separations and employment status are re-estimated, based on the specifications from columns 1 - 4 of the bottom panel of Table 5, replacing the reported discrimination dummy variable with a dummy which equals one if the worker reports discrimination because he was not hired or interviewed because of his age (zero otherwise), and another dummy which equals one if the worker reports discrimination for any other reason (zero otherwise). The results are presented in Table 7 .

The estimated effects of reported age discrimination not related to hiring or interviewing are quite similar to the results reported in Panel B of Table 5, which is not surprising since a small fraction of reports are related to hiring or interviewing. Workers who report discrimination not related to hiring or interviewing in the later years of the survey (after initially reporting no discrimination) are about 66 to 70 percent more likely to separate from their job than workers who never report age discrimination. The effect on job separations of age discrimination related to hiring or interviewing is somewhat smaller than the effect of discrimination not related to hiring, and statistically insignificant. Thus, in this sample of initial non-reporters, which is presumably less susceptible to heterogeneity bias, discrimination reports related to hiring do not appear to reflect the relatively high quit propensities of these workers. Hiring-related discrimination has larger effects on employment status than does discrimination not related to hiring or interviewing. Workers who report discrimination because they were not hired or interviewed are about 70 to 75 percent more likely to experience a spell of non-employment than workers who never report age discrimination. However, these estimates are imprecisely measured, and are at best marginally

\footnotetext{
${ }^{20} \mathrm{Among}$ all workers, about one in four discrimination reports are related to hiring or interviewing.
} 
significant. Workers who report discrimination not related to hiring or interviewing are about 28 to 36 percent more likely to experience a spell of non-employment than workers who never report discrimination.

The validity of our results may also be questioned because of the uncertainty surrounding the timing of the discrimination experience. As noted earlier, the discrimination reports available in the data refer to experiences over the previous five years. Thus it is not clear when the discrimination began, or which employer is at fault when workers held more than one job during the period. We explore the potential ramifications of this data limitation by re-estimating our logit models on a sample restricted to workers with no more than one employer during each of the fiveyear reporting periods, and to workers who initially report no age discrimination. The results, reported in Table 8, are quite similar to our earlier estimates reported in Panel B of Table 5. Controlling for the full set of explanatory variables, workers who report discrimination are approximately 50 percent more likely to separate from their current employer than workers who report no discrimination. The effect of age discrimination on employment status is somewhat smaller, as workers with positive reports are from 32 percent to 41 percent more likely to experience a spell of non-employment than workers who report no discrimination. Although these estimates are based on a very select sample, they corroborate the full-sample results based on the somewhat less accurate classification of workers experiencing discrimination on the current job.

\section{Additional Consequences of Age Discrimination}

Although our evidence suggests that workers who report age discrimination are more likely to experience a spell of non-employment than other workers, we have not explored the likelihood that respondents reporting discrimination retire from the labor force or the duration of their spells of non-employment. These issues are addressed by re-estimating the logit models reported in the 
bottom panel of Table 5 using alternative measures of labor force status as the dependent variable. The results are presented in Table 9. In columns 1 and 2, the dependent variable equals one if the respondent reports retirement as his major activity during the survey week of the subsequent interview (zero otherwise). In columns 3 and 4, the dependent variable equals one if the respondent reports that he is not employed and not looking for work at the time of the subsequent interview (zero otherwise). Finally, in columns 5 and 6 the dependent variable equals one if the respondent is not working in either of the next two interviews (zero otherwise). The estimated coefficients on age discrimination, among workers who initially report no discrimination, are small and statistically insignificant in all of the specifications reported in Table 9, indicating that workers do not respond to age discrimination by retiring or otherwise dropping out of the labor force, and that age discrimination does not generate persistent spells of non-employment. Instead, the effect of age discrimination appears to operate through job separations, which are sometimes followed by relatively short spells of non-employment.

Although this evidence does not indicate that age discrimination leads to early retirement or long spells of non-employment, workers reporting age discrimination who separate from their employers or become non-employed do appear to pay a substantial cost, in the form of lower wages on their new job or when they become re-employed. Table 10 reports ordinary least squares estimates of equations for the change in the log real wage, measured from the time of the report to the subsequent job or re-employment. In column 1, the estimating equation includes the dummy variable for reporting age discrimination. In column 2 , this variable is interacted with dummies indicating whether or not the respondent subsequently left his employer. In column 3 , the age discrimination variable is interacted with dummies indicating whether or not a spell of nonemployment followed. In each column, the specifications also include changes in disability, 
marital status, age and age squared, and SMSA residence. Compared to workers who report no discrimination, the estimated wage change is seven percent lower for workers who report age discrimination and separate from their employer, and 13 percent lower for workers for workers who report age discrimination and experience a subsequent spell of non-employment. Workers who report age discrimination but do not separate from their employer or do not become non-employed do not experience lower wage growth than nonreporters. ${ }^{21}$

\section{Conclusions}

Although economists have devoted considerable effort to investigating sex and race discrimination in the labor market, there has been very little empirical research on the prevalence and consequences of discrimination based on age. The effects of age discrimination are difficult to measure because the standard economic approach to the study of discrimination - attributing to discrimination the differences in labor market outcomes that persist after controlling for all observable differences in productivity-related characteristics - cannot be applied in a compelling fashion to older workers because of the strong possibility that age itself affects individual productivity.

In this paper, we take a different approach by analyzing self-reports of discrimination. We find that about seven percent of our sample of older male workers report that they experienced age discrimination in the workplace during the period 1966 to 1980 . Workers who reported age discrimination were much more likely to separate from their employer and less likely to remain employed, even after controlling for many personal and job characteristics, including the presence of mandatory retirement provisions on the job and general job dissatisfaction. These findings are generally robust to our many attempts to correct our estimates for the inherent limitations of self-

\footnotetext{
${ }^{21}$ This latter finding provides further evidence that age discrimination reports do not simply reflect adverse labor market outcomes, at least insofar as they are reflected in lower wage growth.
} 
reported data, particularly the potential heterogeneity bias that arises from differences in the propensity to report discrimination, and the likelihood of attributing to discrimination other negative labor market outcomes.

Our evidence indicates that age discrimination in the workplace may be (or may have been) a serious problem that provides a basis for legislation restricting discrimination against older workers. Alternative approaches to studying the prevalence and consequences of age discrimination, and for assessing the impact of the ADEA, should be high on the research agenda of those studying older workers in the labor market. 


\section{References}

Blau, David M. 1994. “Labor Force Dynamics of Older Men.” Econometrica 62:117-56.

Bloch, Farrell E. 1994. Antidiscrimination Law and Minority Employment (Chicago: University of Chicago Press).

Bureau of Labor Statistics. 1989. Handbook of Labor Statistics, Bulletin 2340.

Clark, Kim B. and Lawrence H. Summers. 1979. "Labor Market Dynamics and Unemployment: A Reconsideration." Brookings Papers on Economic Activity 1:13-60.

Equal Employment Opportunity Commission. 1994. Annual Report for Fiscal Year 1990. (Washington, D.C.: Government Printing Office).

Fix, Michael and Raymond J. Struyk. 1992. Clear and Convincing Evidence: Measurement of Discrimination in America (Washington, D.C.: The Urban Institute Press).

Friedman, Lawrence. 1984. Your Time Will Come: The Law of Age Discrimination and Mandatory Retirement (New York: Russell Sage Foundation).

Ham, John C. and Samuel A. Rea, Jr. 1987. "Unemployment Insurance and Male Unemployment Duration in Canada." Journal of Labor Economics 5:325-53.

Hellerstein, Judith K., David Neumark and Kenneth R. Troske. 1996. "Wages, Productivity, and Worker Characteristics." Mimeograph.

Hurd, Michael. 1990. "Research on the Elderly: Economic Status, Retirement, and Consumption and Saving." Journal of Economic Literature 28:565-637.

Hutchens, Robert M. 1988. "Do Job Opportunities Decline with Age?" Industrial and Labor Relations Review 42(1):89-99.

Kuhn, Peter J. 1990. "Sex Discrimination in Labor Markets: The Role of Statistical Evidence." American Economic Review 77(4): 567-83.

Lazear, Edward P. 1979. "Why Is There Mandatory Retirement?" Journal of Political Economy 87(6): 1261-84.

Lloyd, Cynthia B. and Beth T. Niemi. 1979. The Economics $f$ Sex Differentials (New York: Columbia University Press).

Neumark, David and Michele McLennan. 1995. "Sex Discrimination and Women's Labor Market Outcomes." Journal of Human Resources 30: 713-40.

Parnes, H.S. and R. King. 1977. "Middle-Aged Job Losers." Industrial Gerontology 4:77-96. 
Quinn, Joseph F., Richard V. Burkhauser, and Daniel A. Myers. 1990. Passing the Torch: The Influence of Economic Incentives on Work and Retirement. (Kalamazoo, MI: W.E. Upjohn Institute for Employment Research).

Rhine, Shirley H. 1978. Older Workers and Retirement (New York: The Conference Board, Inc.).

Rosen, B. and T. H. Jerdee. 1977. "Too Old or Not Too Old?" Harvard Business Review 55:97106.

Ruhm, Christopher J. 1990. "Career Jobs, Bridge Employment and Retirement." In Peter B. Doeringer, ed., Bridges to Retirement: Older Workers in a Changing Labor Market (Ithaca, NY: ILR Press), pp. 92-110. 
Table 1

Descriptive Statistics and Correlates of Reported Age Discrimination, 1966-1980 ${ }^{\mathrm{a}}$

\begin{tabular}{|c|c|c|c|c|}
\hline & \multicolumn{3}{|c|}{ Descriptive Statistics $^{a}$} & \multirow[b]{2}{*}{$\begin{array}{l}\text { Logit estimates } \\
\text { of reported } \\
\text { discrimination } \\
\text { (4) }\end{array}$} \\
\hline & $\begin{array}{c}\text { All workers } \\
\text { (1) }\end{array}$ & $\begin{array}{l}\text { Workers reporting } \\
\text { discrimination in } \\
\text { last } 5 \text { years } \\
(2) \\
\end{array}$ & $\begin{array}{c}\text { Workers not } \\
\text { reporting } \\
\text { discrimination in } \\
\text { last } 5 \text { years } \\
\text { (3) } \\
\end{array}$ & \\
\hline $\begin{array}{l}\text { Reports age discrimination in } \\
\text { last } 5 \text { years }\end{array}$ & $\begin{array}{l}.07 \\
(.002)\end{array}$ & $\ldots$ & $\ldots$ & $\ldots$ \\
\hline Age $\leq 55$ & $\begin{array}{l}.06 \\
(.002)\end{array}$ & $\ldots$ & $\ldots$ & $\ldots$ \\
\hline Age $>55$ & $\begin{array}{l}.08 \\
(.003)\end{array}$ & $\ldots$ & $\ldots$ & $\ldots$ \\
\hline Job separation in next period & $\begin{array}{l}.22 \\
(.003)\end{array}$ & $\begin{array}{l}.37 \\
(.01)\end{array}$ & $\begin{array}{l}.21 \\
(.003)\end{array}$ & $\ldots$ \\
\hline Age $\leq 55$ & $\begin{array}{l}.16 \\
(.004)\end{array}$ & $\begin{array}{l}.29 \\
(.02)\end{array}$ & $\begin{array}{l}.15 \\
(.004)\end{array}$ & $\ldots$ \\
\hline Age $>55$ & $\begin{array}{l}.29 \\
(.005)\end{array}$ & $\begin{array}{l}.44 \\
(.02)\end{array}$ & $\begin{array}{l}.28 \\
(.005)\end{array}$ & $\ldots$ \\
\hline Not working in next period & $\begin{array}{l}.11 \\
(.002)\end{array}$ & $\begin{array}{l}.18 \\
(.01)\end{array}$ & $\begin{array}{l}.11 \\
(.002)\end{array}$ & $\ldots$ \\
\hline Age $\leq 55$ & $\begin{array}{l}.04 \\
(.002)\end{array}$ & $\begin{array}{l}.08 \\
(.01)\end{array}$ & $\begin{array}{l}.04 \\
(.002)\end{array}$ & $\ldots$ \\
\hline Age $>55$ & $\begin{array}{l}.19 \\
(.004)\end{array}$ & $\begin{array}{l}.26 \\
(.02)\end{array}$ & $\begin{array}{l}.18 \\
(.004)\end{array}$ & $\ldots$ \\
\hline $\begin{array}{l}\text { Mandatory retirement in current } \\
\text { job }\end{array}$ & $\begin{array}{l}.47 \\
(.004)\end{array}$ & $\begin{array}{l}.48 \\
(.027)\end{array}$ & $\begin{array}{l}.47 \\
(.005)\end{array}$ & $\begin{array}{c}.29 \\
(.08) \\
{[1.33]}\end{array}$ \\
\hline Pension in 1966 job & $\begin{array}{l}.65 \\
(.003)\end{array}$ & $\begin{array}{c}.60 \\
(.01)\end{array}$ & $\begin{array}{l}.65 \\
(.004)\end{array}$ & $\begin{array}{c}-.16 \\
(.07) \\
{[0.85]}\end{array}$ \\
\hline Health limits work & $\begin{array}{l}.23 \\
(.003)\end{array}$ & $\begin{array}{l}.31 \\
(.01)\end{array}$ & $\begin{array}{l}.22 \\
(.003)\end{array}$ & $\begin{array}{r}.39 \\
(.06) \\
{[1.48]}\end{array}$ \\
\hline Tenure & $\begin{array}{r}14.59 \\
(.08)\end{array}$ & $\begin{array}{l}12.26 \\
(.31)\end{array}$ & $\begin{array}{r}14.77 \\
(.08)\end{array}$ & $\begin{array}{c}-.02 \\
(.003) \\
{[0.98]}\end{array}$ \\
\hline
\end{tabular}


Table 1 (Continued)

\begin{tabular}{|c|c|c|c|c|}
\hline & \multicolumn{3}{|c|}{ Descriptive Statistics $^{\mathrm{a}}$} & \multirow[b]{2}{*}{$\begin{array}{c}\text { Logit estimates } \\
\text { of reported } \\
\text { discrimination } \\
\text { (4) } \\
\end{array}$} \\
\hline & $\begin{array}{c}\text { All workers } \\
\text { (1) }\end{array}$ & $\begin{array}{l}\text { Workers reporting } \\
\text { discrimination in } \\
\text { last } 5 \text { years } \\
(2)\end{array}$ & $\begin{array}{c}\text { Workers not } \\
\text { reporting } \\
\text { discrimination in } \\
\text { last } 5 \text { years } \\
(3) \\
\end{array}$ & \\
\hline Dislikes current job & $\begin{array}{l}.07 \\
(.002)\end{array}$ & $\begin{array}{c}.13 \\
(.01)\end{array}$ & $\begin{array}{l}.06 \\
(.002)\end{array}$ & $\begin{array}{r}.85 \\
(.09) \\
{[2.33]}\end{array}$ \\
\hline Hourly wage (\$1966) & $\begin{array}{c}3.28 \\
(1.97)\end{array}$ & $\begin{array}{c}3.13 \\
(5.81)\end{array}$ & $\begin{array}{c}3.29 \\
(2.07)\end{array}$ & $\begin{array}{c}-.05 \\
(.02) \\
{[1.00]}\end{array}$ \\
\hline Public sector job & $\begin{array}{l}.20 \\
(.003)\end{array}$ & $\begin{array}{c}.17 \\
(.01)\end{array}$ & $\begin{array}{c}.20 \\
(.003)\end{array}$ & $\begin{array}{c}-.30 \\
(.08) \\
{[0.74]}\end{array}$ \\
\hline Age & $\begin{array}{r}55.02 \\
(.04)\end{array}$ & $\begin{array}{r}55.88 \\
(.13)\end{array}$ & $\begin{array}{r}54.95 \\
(.04)\end{array}$ & $\begin{array}{c}.03 \\
(.006) \\
{[1.04]}\end{array}$ \\
\hline Years of schooling & $\begin{array}{l}9.72 \\
(.03)\end{array}$ & $\begin{array}{c}10.15 \\
(.11)\end{array}$ & $\begin{array}{c}9.69 \\
(.03)\end{array}$ & $\begin{array}{c}.06 \\
(.01) \\
{[1.06]}\end{array}$ \\
\hline Non-white & $\begin{array}{c}.30 \\
(.003)\end{array}$ & $\begin{array}{c}.29 \\
(.01)\end{array}$ & $\begin{array}{l}.30 \\
(.003)\end{array}$ & $\begin{array}{c}.05 \\
(.07) \\
{[1.06]}\end{array}$ \\
\hline Married, spouse present & $\begin{array}{c}.89 \\
(.002)\end{array}$ & $\begin{array}{c}.87 \\
(.01)\end{array}$ & $\begin{array}{c}.89 \\
(.002)\end{array}$ & $\begin{array}{c}.26 \\
(.18) \\
{[1.29]}\end{array}$ \\
\hline Divorced or separated & $\begin{array}{l}.05 \\
(.002)\end{array}$ & $\begin{array}{c}.07 \\
(.01)\end{array}$ & $\begin{array}{l}.05 \\
(.002)\end{array}$ & $\begin{array}{c}.56 \\
(.21) \\
{[1.75]}\end{array}$ \\
\hline Widowed & $\begin{array}{c}.03 \\
(.001)\end{array}$ & $\begin{array}{l}.03 \\
(.005)\end{array}$ & $\begin{array}{c}.03 \\
(.001)\end{array}$ & $\begin{array}{c}.27 \\
(.24) \\
{[1.31]}\end{array}$ \\
\hline SMSA & $\begin{array}{c}.73 \\
(.003)\end{array}$ & $\begin{array}{c}.74 \\
(.01)\end{array}$ & $\begin{array}{l}.73 \\
(.003)\end{array}$ & $\begin{array}{c}.07 \\
(.07) \\
{[1.07]}\end{array}$ \\
\hline $\mathrm{N}$ & 19,720 & 1,403 & 18,317 & 19,720 \\
\hline
\end{tabular}

a. Standard errors are reported in parentheses. Means are sometimes based on less than the full sample because of missing data for some variables.

b. Standard errors are reported in parentheses and odds ratios are reported in square brackets. The estimated effect of the real wage is calculated from a separate logit for the subset of years for which wages are available. 
Table 2

Logit Estimates for Job Separations, 1966-1980

\begin{tabular}{|c|c|c|c|c|c|c|c|}
\hline & (1) & (2) & (3) & (4) & (5) & (6) & (7) \\
\hline $\begin{array}{l}\text { Reports age discrimination } \\
\qquad(\mathrm{N}=1,403)\end{array}$ & $\begin{array}{r}.82 \\
(.06) \\
{[2.27]}\end{array}$ & $\begin{array}{c}.83 \\
(.06) \\
{[2.29]}\end{array}$ & $\begin{array}{c}.69 \\
(.07) \\
{[2.00]}\end{array}$ & $\begin{array}{c}.68 \\
(.07) \\
{[1.98]}\end{array}$ & $\begin{array}{c}.65 \\
(.07) \\
{[1.91]}\end{array}$ & $\begin{array}{c}.65 \\
(.07) \\
{[1.92]}\end{array}$ & $\cdots$ \\
\hline $\begin{array}{l}\text { Reports age discrimination } \\
\quad \text { age } \leq 55(\mathrm{~N}=640)\end{array}$ & $\ldots$ & $\cdots$ & $\cdots$ & $\cdots$ & $\cdots$ & $\ldots$ & $\begin{array}{r}.79 \\
(.10) \\
{[2.21]}\end{array}$ \\
\hline $\begin{array}{l}\text { Reports age discrimination } \\
\quad \text { age }>55(\mathrm{~N}=763)\end{array}$ & $\cdots$ & $\cdots$ & $\cdots$ & $\cdots$ & $\cdots$ & $\cdots$ & $\begin{array}{r}.55 \\
(.09) \\
{[1.74]}\end{array}$ \\
\hline Health limits work & $\begin{array}{c}.33 \\
(.04) \\
{[1.39]}\end{array}$ & $\begin{array}{c}.34 \\
(.04) \\
{[1.40]}\end{array}$ & $\begin{array}{c}.32 \\
(.04) \\
{[1.37]}\end{array}$ & $\begin{array}{r}.36 \\
(.04) \\
{[1.07]}\end{array}$ & $\begin{array}{c}.34 \\
(.05) \\
{[1.41]}\end{array}$ & $\begin{array}{c}.30 \\
(.04) \\
{[1.35]}\end{array}$ & $\begin{array}{r}.30 \\
(.04) \\
{[1.35]}\end{array}$ \\
\hline $\begin{array}{l}\text { Subject to mandatory } \\
\text { retirement, age } \leq 55\end{array}$ & $\ldots$ & $\begin{array}{r}-1.09 \\
(.07) \\
{[0.34]}\end{array}$ & $\begin{array}{c}-.55 \\
(.08) \\
{[0.58]}\end{array}$ & $\begin{array}{c}-.70 \\
(.08) \\
{[0.50]}\end{array}$ & $\begin{array}{c}-.72 \\
(.08) \\
{[0.49]}\end{array}$ & $\begin{array}{c}-.57 \\
(.08) \\
{[0.56]}\end{array}$ & $\begin{array}{r}-.58 \\
(.08) \\
{[0.56]}\end{array}$ \\
\hline $\begin{array}{l}\text { Subject to mandatory } \\
\text { retirement, } 55<\text { age } \leq 65\end{array}$ & $\cdots$ & $\begin{array}{c}-.16 \\
(.06) \\
{[0.85]}\end{array}$ & $\begin{array}{c}.28 \\
(.07) \\
{[1.32]}\end{array}$ & $\begin{array}{c}.15 \\
(.06) \\
{[1.17]}\end{array}$ & $\begin{array}{c}.13 \\
(.06) \\
{[1.14]}\end{array}$ & $\begin{array}{c}.26 \\
(.07) \\
{[1.30]}\end{array}$ & $\begin{array}{r}.27 \\
(.07) \\
{[1.31]}\end{array}$ \\
\hline $\begin{array}{l}\text { Subject to mandatory } \\
\text { retirement, age }>65\end{array}$ & $\ldots$ & $\begin{array}{c}.09 \\
(.40) \\
{[1.09]}\end{array}$ & $\begin{array}{c}.51 \\
(.41) \\
{[1.67]}\end{array}$ & $\begin{array}{c}.53 \\
(.41) \\
{[1.7]}\end{array}$ & $\begin{array}{c}.54 \\
(.41) \\
{[1.72]}\end{array}$ & $\begin{array}{c}.53 \\
(.41) \\
{[1.69]}\end{array}$ & $\begin{array}{c}.53 \\
(.41) \\
{[1.69]}\end{array}$ \\
\hline Covered by pension in 1966 & $\ldots$ & $\ldots$ & $\begin{array}{c}-.09 \\
(.05) \\
{[0.92]}\end{array}$ & $\begin{array}{c}-.27 \\
(.05) \\
{[0.76]}\end{array}$ & $\begin{array}{c}-.27 \\
(.05) \\
{[0.76]}\end{array}$ & $\begin{array}{c}-.08 \\
(.05) \\
{[0.92]}\end{array}$ & $\begin{array}{r}-.08 \\
(.05) \\
{[0.92]}\end{array}$ \\
\hline Predicted real log wage ${ }^{b}$ & $\cdots$ & $\ldots$ & $\cdots$ & $\begin{array}{c}.60 \\
(.10) \\
{[1.82]}\end{array}$ & $\begin{array}{r}.62 \\
(.10) \\
{[1.87]}\end{array}$ & $\cdots$ & $\cdots$ \\
\hline Dislikes current job & $\cdots$ & $\cdots$ & $\ldots$ & $\cdots$ & $\begin{array}{r}.55 \\
(.07) \\
{[1.74]}\end{array}$ & $\begin{array}{r}.56 \\
(.07) \\
{[1.74]}\end{array}$ & $\begin{array}{r}.56 \\
(.07) \\
{[1.74]}\end{array}$ \\
\hline
\end{tabular}

(Continued) 
Table 2 (continued)

(1)

(2)

(3)

(4)

(5)

(6)

(7)

Other controls:

Years of schooling

Non-white

Married, spouse present

Divorced or separated

Widowed

SMSA

Age-age ${ }^{4}$

Year dummy variables

Tenure-tenure ${ }^{4}$

Public sector job

One-digit industry and occupation

$\begin{array}{ccccccc}\text { Yes } & \text { Yes } & \text { Yes } & \text { Yes } & \text { Yes } & \text { Yes } & \text { Yes } \\ \text { Yes } & \text { Yes } & \text { Yes } & \text { Yes } & \text { Yes } & \text { Yes } & \text { Yes } \\ \text { Yes } & \text { Yes } & \text { Yes } & \text { Yes } & \text { Yes } & \text { Yes } & \text { Yes } \\ \text { Yes } & \text { Yes } & \text { Yes } & \text { Yes } & \text { Yes } & \text { Yes } & \text { Yes } \\ \text { Yes } & \text { Yes } & \text { Yes } & \text { Yes } & \text { Yes } & \text { Yes } & \text { Yes } \\ \text { Yes } & \text { Yes } & \text { Yes } & \text { Yes } & \text { Yes } & \text { Yes } & \text { Yes } \\ \text { Yes } & \text { Yes } & \text { Yes } & \text { Yes } & \text { Yes } & \text { Yes } & \text { Yes } \\ \text { Yes } & \text { Yes } & \text { Yes } & \text { Yes } & \text { Yes } & \text { Yes } & \text { Yes } \\ \text { No } & \text { No } & \text { Yes } & \text { Yes } & \text { Yes } & \text { Yes } & \text { Yes } \\ \text { No } & \text { No } & \text { Yes } & \text { Yes } & \text { Yes } & \text { Yes } & \text { Yes } \\ \text { No } & \text { No } & \text { Yes } & \text { No } & \text { No } & \text { Yes } & \text { Yes }\end{array}$

Log-likelihood $\begin{array}{lllll}-9614.5 & -9476.7 & -8661.3 & -8785.7 & -8743.4\end{array}$

$-8623.3-8621.7$

a. The sample, which is restricted to respondents with a job, not self-employed, at the time of each survey, includes 19,720 observations. Observations missing data on the dependent variable or reported age discrimination are deleted. For all other variables, missing observations are set to zero, and dummy variables indicating such observations are included in the estimating equation. Standard errors of coefficient estimates are reported in parentheses, and odds ratios are reported in square brackets. b. The real log wage is predicted by an OLS log wage equation estimated on the sample of respondents with valid wage data. In addition to all of the variables in the separation logit, one-digit industry and occupation dummy variables are included in the log wage equation. 
Table 3

Logit Estimates for Employment Status, 1966-1980

\begin{tabular}{|c|c|c|c|c|c|c|c|}
\hline & $(1)$ & $(2)$ & (3) & (4) & $(5)$ & $(6)$ & $(7)$ \\
\hline $\begin{array}{l}\text { Reports age discrimination } \\
\qquad(N=1,403)\end{array}$ & $\begin{array}{c}.60 \\
(.08) \\
{[1.83]}\end{array}$ & $\begin{array}{c}.60 \\
(.08) \\
{[1.83]}\end{array}$ & $\begin{array}{c}.58 \\
(.08) \\
{[1.79]}\end{array}$ & $\begin{array}{r}.57 \\
(.08) \\
{[1.77]}\end{array}$ & $\begin{array}{c}.54 \\
(.08) \\
{[1.72]}\end{array}$ & $\begin{array}{c}.56 \\
(.08) \\
{[1.74]}\end{array}$ & $\cdots$ \\
\hline $\begin{array}{l}\text { Reports age discrimination } \\
\text { age } \leq 55(\mathrm{~N}=640)\end{array}$ & $\ldots$ & $\ldots$ & $\ldots$ & $\cdots$ & $\cdots$ & $\cdots$ & $\begin{array}{c}.82 \\
(.16) \\
{[2.27]}\end{array}$ \\
\hline $\begin{array}{l}\text { Reports age discrimination } \\
\text { age }>55(\mathrm{~N}=763)\end{array}$ & $\ldots$ & $\ldots$ & $\ldots$ & $\cdots$ & $\ldots$ & $\ldots$ & $\begin{array}{c}.47 \\
(.10) \\
{[1.59]}\end{array}$ \\
\hline Health limits work & $\begin{array}{c}.52 \\
(.05) \\
{[1.68]}\end{array}$ & $\begin{array}{r}.52 \\
(.05) \\
{[1.68]}\end{array}$ & $\begin{array}{c}.52 \\
(.06) \\
{[1.69]}\end{array}$ & $\begin{array}{r}.55 \\
(.07) \\
{[1.73]}\end{array}$ & $\begin{array}{r}.53 \\
(.06) \\
{[1.70]}\end{array}$ & $\begin{array}{c}.51 \\
(.06) \\
{[1.66]}\end{array}$ & $\begin{array}{c}.51 \\
(.06) \\
{[1.66]}\end{array}$ \\
\hline $\begin{array}{l}\text { Subject to mandatory } \\
\text { retirement, age } \leq 55\end{array}$ & $\ldots$ & $\begin{array}{c}-.13 \\
(.12) \\
{[0.88]}\end{array}$ & $\begin{array}{c}-.10 \\
(.12) \\
{[0.90]}\end{array}$ & $\begin{array}{c}-.14 \\
(.12) \\
{[0.87]}\end{array}$ & $\begin{array}{c}-.14 \\
(.12) \\
{[0.87]}\end{array}$ & $\begin{array}{c}-.10 \\
(.12) \\
{[0.91]}\end{array}$ & $\begin{array}{c}-.11 \\
(.12) \\
{[0.90]}\end{array}$ \\
\hline $\begin{array}{l}\text { Subject to mandatory } \\
\text { retirement, } 55<\text { age } \leq 65\end{array}$ & $\ldots$ & $\begin{array}{c}.42 \\
(.07) \\
{[1.53]}\end{array}$ & $\begin{array}{c}.40 \\
(.08) \\
{[1.49]}\end{array}$ & $\begin{array}{c}.38 \\
(.08) \\
{[1.46]}\end{array}$ & $\begin{array}{c}.37 \\
(.08) \\
{[1.45]}\end{array}$ & $\begin{array}{c}.40 \\
(.08) \\
{[1.49]}\end{array}$ & $\begin{array}{c}.40 \\
(.08) \\
{[1.50]}\end{array}$ \\
\hline $\begin{array}{l}\text { Subject to mandatory } \\
\text { retirement, age }>65\end{array}$ & $\ldots$ & $\begin{array}{c}-.33 \\
(.44) \\
{[0.72]}\end{array}$ & $\begin{array}{c}-.21 \\
(.46) \\
{[0.81]}\end{array}$ & $\begin{array}{c}-.18 \\
(.45) \\
{[0.83]}\end{array}$ & $\begin{array}{c}-.16 \\
(.45) \\
{[0.85]}\end{array}$ & $\begin{array}{c}-.19 \\
(.45) \\
{[0.83]}\end{array}$ & $\begin{array}{c}-.19 \\
(.45) \\
{[0.83]}\end{array}$ \\
\hline Covered by pension in 1966 & $\ldots$ & $\cdots$ & $\begin{array}{c}.10 \\
(.06) \\
{[1.11]}\end{array}$ & $\begin{array}{c}.03 \\
(.07) \\
{[1.03]}\end{array}$ & $\begin{array}{c}.03 \\
(.07) \\
{[1.03]}\end{array}$ & $\begin{array}{c}.10 \\
(.06) \\
{[1.10]}\end{array}$ & $\begin{array}{c}.11 \\
(.06) \\
{[1.11]}\end{array}$ \\
\hline Predicted real log wage & $\cdots$ & $\ldots$ & $\ldots$ & $\begin{array}{r}.32 \\
(.14) \\
{[1.38]}\end{array}$ & $\begin{array}{c}.35 \\
(.14) \\
{[1.42]}\end{array}$ & $\cdots$ & $\ldots$ \\
\hline Dislikes current job & $\ldots$ & $\ldots$ & $\ldots$ & $\ldots$ & $\begin{array}{c}.48 \\
(.10) \\
{[1.62]}\end{array}$ & $\begin{array}{r}.46 \\
(.10) \\
{[1.59]}\end{array}$ & $\begin{array}{r}.46 \\
(.10) \\
{[1.58]}\end{array}$ \\
\hline Log-likelihood & -5617.1 & -5596.5 & -5470.3 & -5518.7 & -5506.5 & -5459.3 & -5457.5 \\
\hline
\end{tabular}




\begin{tabular}{lcc}
\hline & $(1)$ & $(2)$ \\
\cline { 2 - 3 } & 1.82 & 1.67 \\
Reports age discrimination in & $(.19)$ & $(.19)$ \\
previous self-report, at same & {$[6.16]$} & {$[5.31]$} \\
employer $(\mathrm{N}=170)$ & 1.11 & 1.07 \\
Reports age discrimination in & $(.20)$ & $(.20)$ \\
previous self-report, with & {$[3.02]$} & {$[2.90]$} \\
different employer $(\mathrm{N}=181)$ & Yes & No \\
Predicted real log wage included & No & Yes \\
One-digit industry and occupation & & \\
included & & -1455.2 \\
Log-likelihood & -1473.0 & \\
\hline
\end{tabular}

a. There are 6,089 observations. The sample is smaller than in the previous tables because we use data beginning only in 1973. The specification also includes all variables included in columns 5 and 6 of Table 2, except for the age discrimination variables. See footnotes to Table 2 for details. 
Table 5

Logit Estimates of Job Separations and Employment Status, Distinguishing Workers Who Change Age Discrimination Reports ${ }^{\mathrm{a}}$

\begin{tabular}{|c|c|c|c|c|}
\hline \multicolumn{5}{|c|}{ A. All Workers, $1966-1980^{b}$} \\
\hline & \multicolumn{2}{|c|}{$\underline{\text { Job Separations }}$} & \multicolumn{2}{|c|}{$\underline{\text { Employment Status }}$} \\
\hline & (1) & $(2)$ & (3) & (4) \\
\hline $\begin{array}{l}\text { Reports age discrimination } \\
\text { continuously }(\mathrm{N}=1010)\end{array}$ & $\begin{array}{c}.76 \\
(.08) \\
{[2.13]}\end{array}$ & $\begin{array}{c}.77 \\
(.08) \\
{[2.16]}\end{array}$ & $\begin{array}{c}.81 \\
(.11) \\
{[2.25]}\end{array}$ & $\begin{array}{c}.81 \\
(.11) \\
{[2.24]}\end{array}$ \\
\hline $\begin{array}{l}\text { Switches to reporting age } \\
\text { discrimination }(\mathrm{N}=393)\end{array}$ & $\begin{array}{c}.39 \\
(.12) \\
{[1.48]}\end{array}$ & $\begin{array}{c}.38 \\
(.12) \\
{[1.47]}\end{array}$ & $\begin{array}{c}.17 \\
(.13) \\
{[1.18]}\end{array}$ & $\begin{array}{c}.21 \\
(.13) \\
{[1.23]}\end{array}$ \\
\hline $\begin{array}{l}\text { Switches from reporting age } \\
\text { discrimination }(\mathrm{N}=310)\end{array}$ & $\begin{array}{c}-.02 \\
(.13) \\
{[0.98]}\end{array}$ & $\begin{array}{c}.02 \\
(.14) \\
{[1.02]}\end{array}$ & $\begin{array}{c}-.09 \\
(.15) \\
{[0.92]}\end{array}$ & $\begin{array}{c}-.05 \\
(.15) \\
{[0.96]}\end{array}$ \\
\hline Predicted real log wage included & Yes & No & Yes & No \\
\hline $\begin{array}{l}\text { One-digit industry and occupation } \\
\text { included }\end{array}$ & No & Yes & No & Yes \\
\hline Log-likelihood & -8740.1 & -8619.6 & -5498.7 & -5452.8 \\
\hline \multicolumn{5}{|c|}{ B. Workers Initially Reporting No Age Discrimination, 1973-1980 } \\
\hline & \multicolumn{2}{|c|}{$\underline{\text { Job Separations }}$} & \multicolumn{2}{|c|}{ Employment Status } \\
\hline & $(1)$ & $(2)$ & $(3)$ & $(4)$ \\
\hline $\begin{array}{l}\text { Reports age discrimination } \\
\qquad(\mathrm{N}=369)\end{array}$ & $\begin{array}{c}.46 \\
(.12) \\
{[1.59]}\end{array}$ & $\begin{array}{c}.47 \\
(.12) \\
{[1.61]}\end{array}$ & $\begin{array}{c}.28 \\
(.13) \\
{[1.32]}\end{array}$ & $\begin{array}{c}.33 \\
(.13) \\
{[1.39]}\end{array}$ \\
\hline Predicted real log wage included & Yes & No & Yes & No \\
\hline $\begin{array}{l}\text { One-digit industry and occupation } \\
\text { included }\end{array}$ & No & Yes & No & Yes \\
\hline Log-likelihood & -3060.9 & -3030.4 & -2578.8 & -2548.6 \\
\hline
\end{tabular}

a. There are 19,720 observations in Panel A, and 5,762 observations in Panel B. Additional control variables are the same as in columns 5 and 6 of Tables 2 and 3 . See footnotes to Table 2 for details.

b. The age discrimination reporting variables are defined here as of the year of observation. Thus, observations in 1966-1971 are coded as "reports age discrimination continuously" if workers report age discrimination in 1971. They are coded similarly in 1973-76 if they report age discrimination in 1971 and 1976, and are coded similarly in 1978-80 if they report age discrimination in 1971, 1976, and 1980. Observations in 1972-1976 are coded as "switches to reporting age discrimination" if they report no age discrimination in 1971 and age discrimination in 1976. They are coded similarly for 1978-1980 if they report no age discrimination in 1971, no age discrimination in 1976, or no age discrimination in both 1971 and 1976. Observations are coded as switches from reporting age discrimination in parallel fashion. 
Table 6

Logit Estimates of Job Separations and Employment Status, Among Non-Whites Only ${ }^{\mathrm{a}}$

\section{A. All Workers, 1966-1980}

Job Separations

(1)

Reports age discrimination

$$
(\mathrm{N}=405)
$$

Reports other type of discrimination $(\mathrm{N}=390)$

Predicted real log wage included

One-digit industry and occupation included

Log-likelihood
.73

(.13)

[2.07]

.37

(.14)

[1.45]

Yes

No

$-2624.8$
(2)

.73

Employment Status

(3)

.63

.62

(.15)

[1.88]

[1.86]

.19

.19

(.18)

[1.21]

[1.21]

[1.39]

Yes

No

No

Yes

Yes

$-2590.2$

$-1782.5 \quad-1761.5$

\section{B. Workers Initially Reporting No Age Discrimination, 1973-1980}

Job Separations

Reports age discrimination

$$
(\mathrm{N}=83)
$$

Reports other type of discrimination

$$
(\mathrm{N}=108)
$$

Predicted real log wage included

One-digit industry and occupation included

Log-likelihood
(1)

(2)

.47

[1.60]

[1.75]

.01

(.26)

[1.01]

Yes

No

$-892.1$
Employment Status

(3)

.31

[1.36]

.04

(.29)

[1.04]

[1.03]

Yes

No

No

Yes

a. There are 5,968 observations in Panel A, and 1,740 observations in Panel B. Other types of discrimination include discrimination based on race, religion, and nationality. Additional control variables are the same as in columns 5 and 6 of Tables 2 and 3 . See footnotes to Table 2 for details. 
Table 7

Logit Estimates of Job Separations and Employment Status, 1966-1980,

Distinguishing Basis for Age Discrimination Reports, Among Workers Who Initially Report No Discrimination ${ }^{a}$

\begin{tabular}{|c|c|c|c|c|}
\hline & \multicolumn{2}{|c|}{$\underline{\text { Job Separations }}$} & \multicolumn{2}{|c|}{ Employment Status } \\
\hline & (1) & $(2)$ & (3) & (4) \\
\hline $\begin{array}{l}\text { Reports age discrimination not related } \\
\text { to hiring or interviewing } \\
(\mathrm{N}=310)\end{array}$ & $\begin{array}{c}.51 \\
(.13) \\
{[1.66]}\end{array}$ & $\begin{array}{c}.53 \\
(.13) \\
{[1.70]}\end{array}$ & $\begin{array}{r}.25 \\
(.15) \\
{[1.28]}\end{array}$ & $\begin{array}{c}.30 \\
(.15) \\
{[1.36]}\end{array}$ \\
\hline $\begin{array}{l}\text { Reports not hired or interviewed } \\
\text { because of age }(\mathrm{N}=37)\end{array}$ & $\begin{array}{c}.36 \\
(.36) \\
{[1.43]}\end{array}$ & $\begin{array}{c}.35 \\
(.36) \\
{[1.42]}\end{array}$ & $\begin{array}{c}.53 \\
(.37) \\
{[1.70]}\end{array}$ & $\begin{array}{r}.56 \\
(.38) \\
{[1.75]}\end{array}$ \\
\hline Health limits work & $\begin{array}{c}.31 \\
(.07) \\
{[1.36]}\end{array}$ & $\begin{array}{c}.28 \\
(.07) \\
{[1.32]}\end{array}$ & $\begin{array}{c}.44 \\
(.08) \\
{[1.55]}\end{array}$ & $\begin{array}{r}.42 \\
(.08) \\
{[1.52]}\end{array}$ \\
\hline $\begin{array}{l}\text { Subject to mandatory retirement, } \\
\text { age } \leq 55\end{array}$ & $\begin{array}{c}-.53 \\
(.39) \\
{[0.59]}\end{array}$ & $\begin{array}{c}-.40 \\
(.39) \\
{[0.67]}\end{array}$ & $\begin{array}{c}-.10 \\
(.45) \\
{[0.91]}\end{array}$ & $\begin{array}{c}-.03 \\
(.45) \\
{[0.97]}\end{array}$ \\
\hline $\begin{array}{l}\text { Subject to mandatory retirement, } \\
55<\text { age } \leq 65\end{array}$ & $\begin{array}{r}.42 \\
(.10) \\
{[1.51]}\end{array}$ & $\begin{array}{c}.49 \\
(.11) \\
{[1.64]}\end{array}$ & $\begin{array}{c}.53 \\
(.11) \\
{[1.70]}\end{array}$ & $\begin{array}{c}.56 \\
(.11) \\
{[1.75]}\end{array}$ \\
\hline $\begin{array}{l}\text { Subject to mandatory retirement, } \\
\quad \text { age }>65\end{array}$ & $\begin{array}{c}.52 \\
(.44) \\
{[1.68]}\end{array}$ & $\begin{array}{c}.47 \\
(.44) \\
{[1.61]}\end{array}$ & $\begin{array}{c}.19 \\
(.46) \\
{[1.21]}\end{array}$ & $\begin{array}{c}.14 \\
(.47) \\
{[1.15]}\end{array}$ \\
\hline Covered by pension in 1966 & $\begin{array}{c}-.02 \\
(.08) \\
{[0.98]}\end{array}$ & $\begin{array}{c}.10 \\
(.08) \\
{[1.11]}\end{array}$ & $\begin{array}{c}.23 \\
(.09) \\
{[1.26]}\end{array}$ & $\begin{array}{c}.29 \\
(.09) \\
{[1.34]}\end{array}$ \\
\hline Predicted real log wage & $\begin{array}{c}.45 \\
(.18) \\
{[1.56]}\end{array}$ & $\cdots$ & $\begin{array}{c}.22 \\
(.20) \\
{[1.25]}\end{array}$ & $\cdots$ \\
\hline Dislikes current job & $\begin{array}{c}.36 \\
(.14) \\
{[1.43]}\end{array}$ & $\begin{array}{c}.33 \\
(.14) \\
{[1.39]}\end{array}$ & $\begin{array}{c}.42 \\
(.15) \\
{[1.52]}\end{array}$ & $\begin{array}{r}.42 \\
(.15) \\
{[1.52]}\end{array}$ \\
\hline Log-likelihood & -3039.9 & -3010.3 & -2561.1 & -2532.4 \\
\hline
\end{tabular}

a. The sample is restricted to individuals who report no discrimination in 1971. A handful of observations with missing occupation and industry data are deleted in order to achieve convergence. There are 5,728 observations. Additional control variables in columns 1 and 3 are the same as in column 5 of Tables 2 and 3. Additional control variables in columns 2 and 4 are the same as in column 6 of Tables 2 and 3 . See footnotes to Table 2 for additional details. 
Table 8

Logit Estimates of Job Separations and Employment Status, 1973-1980, Among Workers With Only One Employer Per Reporting Period

Who Initially Report No Discriminationa

\begin{tabular}{|c|c|c|c|c|}
\hline & \multicolumn{2}{|c|}{$\underline{\text { Job Separations }}$} & \multicolumn{2}{|c|}{ Employment Status } \\
\hline & $(1)$ & $(2)$ & (3) & (4) \\
\hline $\begin{array}{l}\text { Reports age discrimination } \\
\qquad(\mathrm{N}=279)\end{array}$ & $\begin{array}{c}.40 \\
(.15) \\
{[1.49]}\end{array}$ & $\begin{array}{c}.45 \\
(.15) \\
{[1.57]}\end{array}$ & $\begin{array}{c}.28 \\
(.15) \\
{[1.32]}\end{array}$ & $\begin{array}{c}.34 \\
(.16) \\
{[1.41]}\end{array}$ \\
\hline Health limits work & $\begin{array}{c}.41 \\
(.08) \\
{[1.51]}\end{array}$ & $\begin{array}{c}.39 \\
(.08) \\
{[1.48]}\end{array}$ & $\begin{array}{c}.44 \\
(.08) \\
{[1.55]}\end{array}$ & $\begin{array}{c}.43 \\
(.08) \\
{[1.53]}\end{array}$ \\
\hline $\begin{array}{l}\text { Subject to mandatory retirement, } \\
\text { age } \leq 55\end{array}$ & $\begin{array}{c}-.26 \\
(.42) \\
{[0.77]}\end{array}$ & $\begin{array}{c}-.18 \\
(.42) \\
{[0.83]}\end{array}$ & $\begin{array}{c}.11 \\
(.45) \\
{[1.11]}\end{array}$ & $\begin{array}{c}.16 \\
(.45) \\
{[1.18]}\end{array}$ \\
\hline $\begin{array}{l}\text { Subject to mandatory retirement, } \\
55<\text { age } \leq 65\end{array}$ & $\begin{array}{c}.52 \\
(.11) \\
{[1.68]}\end{array}$ & $\begin{array}{c}.58 \\
(.11) \\
{[1.78]}\end{array}$ & $\begin{array}{c}.59 \\
(.12) \\
{[1.81]}\end{array}$ & $\begin{array}{c}.62 \\
(.12) \\
{[1.87]}\end{array}$ \\
\hline $\begin{array}{l}\text { Subject to mandatory retirement, } \\
\text { age }>65\end{array}$ & $\begin{array}{c}.40 \\
(.45) \\
{[1.50]}\end{array}$ & $\begin{array}{c}.35 \\
(.46) \\
{[1.41]}\end{array}$ & $\begin{array}{c}-.04 \\
(.49) \\
{[0.96]}\end{array}$ & $\begin{array}{c}-.11 \\
(.50) \\
{[0.90]}\end{array}$ \\
\hline Covered by pension in 1966 & $\begin{array}{c}.18 \\
(.10) \\
{[1.19]}\end{array}$ & $\begin{array}{c}.26 \\
(.09) \\
{[1.30]}\end{array}$ & $\begin{array}{c}.26 \\
(.10) \\
{[1.30]}\end{array}$ & $\begin{array}{c}.31 \\
(.09) \\
{[1.36]}\end{array}$ \\
\hline Predicted real log wage & $\begin{array}{c}.32 \\
(.20) \\
{[1.38]}\end{array}$ & $\cdots$ & $\begin{array}{c}.15 \\
(.21) \\
{[1.17]}\end{array}$ & ... \\
\hline Dislikes current job & $\begin{array}{c}.35 \\
(.15) \\
{[1.42]}\end{array}$ & $\begin{array}{c}.34 \\
(.15) \\
{[1.40]}\end{array}$ & $\begin{array}{c}.38 \\
(.16) \\
{[1.47]}\end{array}$ & $\begin{array}{c}.39 \\
(.16) \\
{[1.48]}\end{array}$ \\
\hline Log-likelihood & -2400.6 & -2373.7 & -2228.9 & -2199.0 \\
\hline
\end{tabular}

a. The sample is restricted to respondents who report no discrimination in 1971 and who work for at most one employer during each of the periods 1973-1976 and 1978-1980. There are 5,007 observations. Additional control variables in columns 1 and 3 are the same as in column 5 of Tables 2 and 3. Additional control variables in columns 2 and 4 are the same as in column 6 of Tables 2 and 3 . See footnotes to Table 2 for additional details. 
Table 9

\section{Logit Estimates of Labor Force Status, 1973-1980 Among Workers Who Initially Report No Discrimination}

\begin{tabular}{lccccccc}
\hline & \multicolumn{2}{c}{ Retired } & \multicolumn{2}{c}{$\begin{array}{c}\text { Not Employed, Not } \\
\text { Looking for Work }\end{array}$} & \multicolumn{2}{c}{$\begin{array}{c}\text { Not Employed } \\
\text { for Two Periods }\end{array}$} \\
& $(1)$ & $(2)$ & $(3)$ & $(4)$ & $(5)$ & $(6)$ \\
\cline { 2 - 8 } Reports age discrimination & -.05 & -.02 & .07 & .12 & .14 & .19 \\
& $(.16)$ & $(.16)$ & $(.14)$ & $(.15)$ & $(.15)$ & $(.15)$ \\
Predicted log wage included & {$[0.95]$} & {$[0.98]$} & {$[1.08]$} & {$[1.13]$} & {$[1.15]$} & {$[1.21]$} \\
One-digit industry and & Yes & No & Yes & No & Yes & No \\
occupation included & No & Yes & No & Yes & No & Yes \\
Log-likelihood & & & & & & & \\
\hline
\end{tabular}

a. The sample is restricted to individuals who report no discrimination in 1971. A handful of observations with missing occupation and industry data are deleted in order to achieve convergence. There are 5,728 observations. Additional control variables in columns 1, 3, and 5 are the same as in column 5 of Tables 2 and 3 . Additional control variables in columns 2, 4, and 6 are the same as in column 6 of Tables 2 and 3 . See footnotes to Table 2 for additional details.

b. The dependent variable equals one if respondent reports retirement as his major activity during subsequent interview, zero otherwise.

c. The dependent variable equals one if respondent does not report working or looking for work at subsequent interview, zero otherwise.

d. The dependent variable equals one if respondent is not employed at either of the two subsequent interviews, zero otherwise. 
Table 10

Effects of Age Discrimination on Wage Changes

(OLS estimates, with standard errors in parentheses)

\begin{tabular}{llll}
\hline & $(1)$ & $(2)$ & $(3)$ \\
\cline { 2 - 4 } & -.01 & $\ldots$ & $\ldots$ \\
Reports age discrimination & $(.01)$ & & \\
& $\ldots$ & -.07 & $\ldots$ \\
$\begin{array}{l}\text { Reports age discrimination and } \\
\quad \text { separates from employer }\end{array}$ & & $(.02)$ & \\
$\begin{array}{l}\text { Reports age discrimination and does } \\
\quad \text { not separate from employer }\end{array}$ & $\ldots$ & .02 & $\ldots$ \\
$\begin{array}{l}\text { Reports age discrimination and } \\
\quad \text { experiences spell of non-employment }\end{array}$ & $\ldots$ & $(.02)$ & \\
$\begin{array}{l}\text { Reports age discrimination and does } \\
\text { not experience spell of non-employment }\end{array}$ & $\ldots$ & $\ldots$ & -.13 \\
& & & $(.04)$ \\
Adjusted $\mathrm{R}^{2}$ & .02 & & .002 \\
\hline
\end{tabular}

a. The dependent variable is the change in the real log wage. Changes in disability, marital status, age, age squared, and SMSA residence are also included in the specification. $\mathrm{N}=10,096$. 